\title{
12. Rewriting Proust
}

\author{
Working with Chantal Akerman on LA CAPTIVE \\ - A Dialogue
}

Eric de Kuyper and Annie van den Oever

On October 5, 2015, the widely renowned Belgian filmmaker, Chantal Akerman, took her own life. Her untimely death prompted an outpouring of sadness about the loss of an extraordinary filmmaker, who has been celebrated ever since her masterpiece JEANNE DIELMAN, 23 QUAI DU COMMERCE, 1080 BRUXELLES made her famous in 1975 at the age of 25 .

The Belgian filmmaker, writer, and film scholar, Eric de Kuyper, who, like Akerman, had been living and working in Brussels at the time, met her for the first time in his capacity as film critic. As he recalled shortly after her death, that was in 1968: Akerman brought him her first film, SAUTE MA VILLE / BLOW UP MY TOWN (1968) after having been sent to see him by the filmmaker, André Delvaux "for good reasons. At the time I had a film program on Flemish Television (BRT), DE ANDERE FILM / THE OTHER MOVIE. I showed experimental films, underground movies, and other bizarre things. I was impressed by the direct spontaneity of the film as well as by the maker. So of course I showed the film [on Flemish Television]" (De Kuyper and Van den Oever 2015). At the time, Akerman struck him as being a very young girl, thinking that she was only 16 years old, although she was actually 18 .

They not only became friends and remained so for most of her life, but they also worked closely together on several projects, including LA CAPTIVE (2000). De Kuyper made several films himself, including NAUGHTY BoYs (1984) and, more recently, MY LIFE AS AN ACTOR (2015). This dialogue reassesses within the personal context of their friendship, the writing projects they worked on together. Proust played an important role in their joint reading and writing, and this dialogue deals mainly with their joint work on Proust for LA CAPTIVE.

Annie van den Oever: You have been working on and off on Proust adaptations for film and the theater over many years. For instance, you adapted and translated $A$ la recherche du temps perdu into Dutch (with Céline Linssen) for Ro-Theatre, which was turned into four evenings in the theater by the well-known Flemish director, Guy Cassiers. As an essayist and novelist, you wrote about Proust in your nonfiction work Het teruggevonden kind (the child rediscovered), in which you addressed the question of how different 
writers wrote about and rediscovered their childhood years while writing fiction or nonfiction. In that book, Proust seems to have been a source of inspiration to you once again and, after working with Chantal Akerman on LA CAPTIVE, you adapted the script for the theater:Les intermittences du coeur. What made you want to work on the notoriously unfilmable Proust together? Eric de Kuyper: Since her adolescence, Chantal was an obsessive reader actually more than being a film buff. She discovered À la recherche when she was still at school, whereas I read it some years later (in 1971), initially because of her warm recommendation. At the time, she had no thought of making a film based on Proust. On the contrary, Chantal developed her own film oeuvre, alternating between fiction and documentary, and writing her own scenarios. A not-so-happy interlude was her project to adapt Isaac Bashevis Singer's two novels about nineteenth-century Jewish life in Poland, The Manor and The Estate. This would have been a big production, and needed Hollywood-scale participation. I worked with her on a script, which I think was quite impressive. However, the film was never made. She was rather uneasy about one aspect of the project: the historical background. She pretended not to have a "historical imagination," claiming that she could not "see the past." AvdO: So what about the past in Proust, then?

EdK: When she asked me to work on an adaptation of Proust in 1999, I was rather surprised. Having just reread the work, with much more pleasure than the first time, I was curious to find out how she would approach this complex and labyrinthine novel, with its fabulous cast of characters, its rich evocation of a period and society and, above all, its intricate plot. Volker Schlöndorff made his Proust film Swann IN Love in 1984 and Raoul Ruiz his LE TEMPS RETROUVÉ in 1999. Sadly, the Visconti-Pinter project was never realized.

AvdO: But you wanted to find out how she intended to approach Proust, already knowing what she liked and did not like in films in general?

EdK: Indeed. I went to the movies with Chantal a lot, at times when we were working and living together so, for instance, I could easily imagine how she would have reacted to a film like INCEPTION (2010). After ten minutes or so, she would have fallen asleep, waking up just ten minutes before the end. She would, however, have a clear opinion about the movie - in this case, probably something like: "I don't like the works by Escher ..." At the time, however, I thought, how strange that she would have wanted to make a film of Proust's À la recherche du temps perdu. It was certainly one of the more complex literary works of all time and one about which so much has been written in all languages.

AvdO: Was she fascinated by Proust's complexity? 
EdK: I don't think so. From the beginning, there was no doubt in Chantal's mind: much as she liked many episodes in the novel, and was fascinated by the many colorful characters, she only wanted to make the film about the relationship between Marcel and Albertine. More precisely, she wanted to work on the theme of "jealousy in a love affair." So, without any problem, she could rid herself of the historical context of Proust's novel.

AvdO: No "things past," then, in this film?

EdK: No things past, no "remembrance." From the start, this was to be a film in the present tense, and strictly chronological, which could be considered very "anti-Proustian."

AvdO: And what about the plot, if the film was meant to focus on the relationship between Marcel and Albertine?

EdK: In her fiction, Chantal was rarely interested in a plot. She thought of a film story as characters in specific situations and, of course, of characters in different locations. After all, she was also the very talented documentary filmmaker that we know, and her way of developing film narratives was always to work in the present, in the continuity of time. Flashbacks, she felt, were "obscene" or "unnatural." So, in LA CAPTIVE, the character of Marcel was central, and the object of his jealousy, Albertine, more or less secondary. As there was already a film called LA PRISONNIÈRE (Henri-Georges Clouzot, 1968), which is actually the French title of the novel that tells the story of Marcel and Albertine, Chantal chose an equivalent which is, perhaps, still more evocative: LA CAPTIVE - the captivated. This title also suggests the ambivalence of "captivation." Who is captivating whom?

AvdO: As you told me soon after Chantal Akerman's death, to your own surprise, writing the script proved quite easy.

EdK: Yes, it was, except for one passage, which I will come back to. We were also quite surprised at how good - meaning "how useful for an Akerman movie" - the original dialogue turned out to be. That's to say, it completely satisfied Chantal, in terms of how she wanted the tonality of LA CAPTIVE to be. It was rarely difficult to cut the written dialogue and, if necessary, add our own in a natural "Proustian" style! We felt like the writer himself, working on his manuscript (as we know from his own manuscripts and what he called his "paperoles"): erasing, adding, changing ... We were rewriting Proust, which is a curious and exciting experience.

AvdO: Rewriting? So this was not really a literary adaption?

EdK: It wasn't ... She liked dialogue, people who talk, but none of her films, and certainly not LA CAPTIVE, are what one could call "literary" in the way that, for instance, those of Marguerite Duras are. And psychological portraiture was not Chantal's thing either: she wanted the emotions to be 
there, filling the context or, rather, emanating from the context: most of all from, and in, the rooms. Everyday life with a twist, one could say (as we might say of her JeAnne Dielman).

Therefore, is it not strange that this adaptation, which refused many of the Proustian devices is, in the end, so close to Proust's universe? This, even the most traditional Proustians have to admit, don't you think? AvdO: LA CAPTIVE focuses on a very small part of $\grave{A}$ la recherche?

EdK: Yes - on a very small fragment of one part of $A$ la recherche: magnifying it and then observing with the camera-lens what happens. Moreover, the novel itself does not have a real ending for the Marcel-Albertine relationship, which in a typical Proustian fashion, flows away ... and, we felt, not in the most satisfactory manner. The hesitations of the novelist did not seem useful for the conclusion of our movie. To end a film narrative is to affirm that "this is a movie." An installation, or any other way of looking at a "movie," never has the temporal closure that a film intended for viewing in a theater has.

Thus, the ending, not so much in terms of content (the dialogue) as in context and location, includes the most radical changes. The couple is in a kind of union-disunion state (compare this, for instance, with Rossellini's VIAGGIO IN ITALIA, 1954), on their way to Biarritz, where they will stay at the fabulous Hotel du Palais. After the enclosure of the Parisian apartment, it becomes a kind of road-movie.

AvdO: How was your joint work organized practically?

EdK: We rarely worked together on a script for more than two hours a day, in the morning. In the afternoon, Chantal wrote some scenes that we had discussed in our morning session. But all day long, during our cooking, shopping, reading, we never stopped thinking and talking about the film. During our daily chats, I reminded Chantal of A STAR Is BORN (George Cukor, 1954) where, near the end, through the reflections in the big windows, one sees James Mason swimming far away into the sea. I also told her that, when I was working for the cinémathèque in Amsterdam, I used to screen a short silent film, ZWEIMAL GELEBT (Max Mack, 1912), in which we see, in a very long shot, a woman rowing on a lake.

In LA CAPTIVE, it is Marcel who is seen rowing in such a way in the last shot, having failed to save Albertine from her - accidental or voluntary? - death by drowning. I used to screen that silent film accompanied by Rachmaninov's The Isle of the Dead, a piece that Chantal eventually used in her film.

So even if some ideas came from me as her cowriter, Chantal never allowed me to write them down. She was the writer. I want to admit this, not because I felt frustrated as a cowriter. On the contrary: it is rather exciting to 
identify yourself with somebody else's imagination. In a way, it is like acting: becoming another character. I always think that I am there as cowriter, only to help the filmmaker I work with in making a script as rich and as close to their vision as possible. A cowriter is not a cofilmmaker; in fact, as a filmmaker, I make films my own way!

AvdO: You have already said that she was a writer.

EdK: The written word was the real basis of her filming, at least for her fiction. She only felt safe to embark on the shooting phase when the script was finished the way she wanted it: carefully written. For filming fiction, she needed text! This was not the case for her nonfiction films. I contrast this with another filmmaker whom I have worked with several times, the Swiss Jacqueline Veuve, who could not make her documentaries without careful research, which to my eyes, knowing her way of shooting and editing, was a purely academic exercise (well, she was an anthropologist). Chantal went into the making of her nonfiction, her documentaries, without any serious preparation: "J'étais là; telle chose m'advint" (I was there, and this happened to me). It was the French poet, Jean de la Fontaine, who said this, but it could be the programmatic saying of a journalist. Of course, for films such as Hotel Monterey (1975), News From Home (1977), Sud (1999), D’Est (1993), the positioning of her camera-look was chosen with care. But she did not read and study dozens of books before shooting, like Jacqueline Veuve. AvdO: When the script of LA CAPTIVE was finished, and the production under way, the perilous phase of casting Marcel and Albertine began ...

EdK: Chantal's choices were rather surprising. I could see why she wanted Sylvie Testud for Albertine, and I think it was the right decision not to have chosen a more glamorous actress. Indeed, Testud gives a very contemporary touch to Albertine. However, I had my doubts about Stanislas Merhar. His appearance is as far from the images of Proust/Marcel as one can imagine. For a start, he doesn't look like an intellectual ... But after seeing the film, I was totally convinced that her choice was right. Merhar had the behavior and appearance of a rich boy, spoiled, incapable of being immersed in a great love affair. His smoothness was in contrast to a tender fragility. Indeed, a more conventional actor would have taken us back to the past, the historical background of the novel. With the choice of Merhar and Testud, contemporaneity was there right from the start.

AvdO: You worked on other projects together, didn't you?

EdK: Apart from LA CAPTIVE and the Singer project, I worked with Chantal on other adaptations. Most of them were abandoned, like Patricia Highsmith's The Price of Salt (later made by Todd Haynes as CAROL, 2015). We were not satisfied with the last part of the novel: we didn't know what to do with the child. 
In my opinion, this problem was not solved by Haynes either. As for the adaptation of Colette's Chéri (which would have been coupled in our version with La Fin de Chéri), we completed a very satisfactory script, again in a contemporary setting, but had to stop because of problems with the rights, which happened to be sold already to Stephen Frears, as we found out; and his version of CHÉRI came out in 2009. All these years, when not working on her own fiction, or on documentaries and later installations, Chantal also regularly talked about her wish to work on "a Dostoevsky." I think Robert Bresson's UNE FEMME DOUCE (1969) shows that adapting Dostoevsky would not have been impossible for her. Bresson's film has a contemporary setting, too. AvdO: And Joseph Conrad?

EdK: She worked on Conrad's Almayer's Folly, which became the last fiction film she made, in 2011. I would like to add this. I already mentioned how writing was important to Chantal. May I say that her real, hidden ambition was to be a writer! All the years we worked together, I was impressed by her passion for the written word. I regularly told her that she should work in that direction, too. "I'm too lazy," she would say. Lazy? Well, for working on a novel one must have a kind of discipline that she perhaps did not have. One is on one's own as a writer. In filmmaking, however, the team functions much like a mechanic obliging the film director to keep going!

Maybe this was one of the reasons why her relationship with someone like Marguerite Duras, a writer and filmmaker, was always tense (although they had Delphine Seyrig as a mutual friend). Anyway, Akerman wrote two autobiographical texts: Une famille à Bruxelles (1998) and Ma mère rit (2013). AvdO: Did you also like her as a writer?

EDK: As a writer, I learned a lot from the way in which she wrote: "Just put it down like you are saying it." At the beginning of our friendship, I often wondered why her pictures were so good. "How do you do it?" I asked her. "You just click ..." In the same way, she taught me how to cook: you just do it! Always fresh and direct.

\section{References and Further Reading}

Akerman, Chantal. 1998. Une famille à Bruxelles. Paris. L'Arche Éditeur.

—. 2013. Ma mère rit. Paris: Mercure de France.

De Kuyper, Eric, and Annie van den Oever. 2015. "Temps mort: Speaking about Chantal Akerman (1950-2015)." Necsus (Fall). https://necsus-ejms.org/temps-mort-speaking-about-chantalakerman-1950-2015/. 